\title{
POST-JUDGMENT INTEREST - AVOIDING THE CANADA INTEREST ACT
}

\author{
Dr. Eugene Meehan*
}

There has been a rash of recent cases on the amount of interest that can be recovered subsequent to a judgment being obtained. This is, no doubt, to some extent a consequence of the economic downturn resulting in civil actions and eventual judgments in areas such as mortgages, promissory notes, debentures, guarantees, indeed in any area of the law where an amount of interest can be contracted in advance. Such is not restricted to the corporate-commercial sphere, but also includes, for example, matrimonial separation agreements.

Some jurisprudence had held that a successful plaintiff's claim to interest on a judgment was limited to five percent due to section 13 of the Canada Interest Act, which states: "Every judgment debt shall bear interest at the rate of five percent per annum until it is satisfied."' Examples of this approach include Edelweiss Credit Union v. Boehm ${ }^{2}$ and Pacific Savings and Mortgage Corporation v. Foresthill Development and Investment Co. Ltd. ${ }^{3}$ Five percent is unrealistic in view of current interest rates, and could be an encouragement to a debtor to delay payment as much as possible in order that the debtor may invest his funds at a high rate of interest and only pay out interest at the statutory rate when judgment is eventually met.

The Alberta Court of Appeal has confirmed in a recent unreported judgment that unless the interest clause was properly drafted, which was not the case here, section 13 of the federal Interest Act precluded the recovery of post-judgment interest at the rate set out in the agreement. ${ }^{4}$

* LL.B. (Edinburgh), LL.M. (McGill), LL.B. (Ottawa), PH.D. (McGill); of the Faculty of Law, University of Alberta, and the Law Society of Alberta.

1. R.S.C. 1970 , C. 1-18. Recently held to be constitutionally valid federal legislation, hence rendering contrary non-federal legislation inoperative: Governor and Company of Adventurers of England Trading Into Hudson's Bay v. Bland (1982) 136 D.L.R. (3d) 702 (N.W.T.S.C.). In Alberta, the judicially discretionary interest provision, section 15 of the Judicature Act R.S.A. 1980 c. J-1 ("In addition to the cases in which interest is payable by law or may be allowed by law, when in the opinion of the Court the payment of a just debt has been impruperly withheld and it seems to the Court fair and equitable that the party in default should make compensation by the payment of interest, the Court may allow interest for the time and at the rate the Court thinks proper"), has been narrowly construed by Stevenson $J$. (as he then was) so as to avoid conflict with the federal Interest Act: Bank of Nova Scotia v. U.P.C. Holdings Ltd. (1980) 11 Alta. L.R. (2d) 331 (Q.B.). For a history of the section, see Spenrath Construction Ltd. v. 206763 Holdings Ltd. (1982) 32 A. R. 216 at 228 (Q.B., Master in Chambers) per Master Funduk. Section 2 of the Interest Act is as follows: "Except as otherwise provided by this or by any other Act of the Parliament of Canada, any person may stipulate for, allow and enact, on any contract or agreement whatever, any rate of interest or discount that is agreed upon."

2. (1979) 6 R.P.R. 349 (B.C.S.C.).

3. (1981) 25 B.C.L.R. 171 (S.C.).

4. Zero Stores (Sask.) Ltd. v. K.A.H. Investments Ltd., unreported, Oct. 5, 1982, J.D. Calgary, Appeal Sittings 14391. 
The case involved a promissory note upon which judgment in the amount of $\$ 188,295.75$ had been obtained against two individuals. ${ }^{5}$

However, as Master in Chambers Funduk has recently written, "Section 13 fills a void. It does not create an impregnable wall" ${ }^{6}$ The wall can be overcome by up to date and proper drafting, with a view to recent jurisprudential developments. Nevertheless, unless otherwise and explicitly agreed, and assuming up-to-date drafting, it is clear that interest at only five percent is payable. ${ }^{7}$

Recent cases have, however, come to the conclusion that a higher and more realistic rate of interest, in excess of the five percent federal Interest Act limitation, and despite said Act, can be contracted for in advance but only if the particular clause is properly drafted and is clear and unambiguous. ${ }^{8}$

Rather than delve into a detailed analysis of each of these cases in turn, it would be more to the benefit of an Alberta legal practitioner to have a ready-made post-judgment interest clause, derived from and drafted on the basis of these cases, in order that the clause can be utilised (and amended as appropriate) in a mortgage, guarantee, loan agreement, debenture, separation agreement, etc. The cases are nevertheless noted herein for those who wish to read further; should the reader be involved in litigation on interest clauses, the cases would of course require detailed perusal. The main issues the courts have found with interest clauses and which, therefore, should be addressed in a post-judgment interest clause are: non-merger of the covenant to pay interest, or of any other covenant; the continuing obligation to pay interest before and after maturity, default, and judgment; waiver of section 13 of the Canada Interest Act; and running of interest on the judgment itself. A post-judgment interest

5. The promissory note had referred to interest payable before and after maturity and default, and though it is implicitly true that the period of time after judgment is after maturity and default, the Alberta Court of Appeal held that this is insufficient, that "after judgment" should have been explicitly referred to (see p. 9 of the unreported judgment by Laycraft J.A., for the Court).

6. Spenrath Construction Ltd. v. 206763 Holdings Ltd., supran. 1 at 232.

7. Harris v. Harris (1981) 21 B.C.L.R. 145 at 153 (S.C.). Here the order for payment of interest (on arrears of matrimonial maintenance) was made only from the date of judgment to payment. See also Spenrath Construction Lld. v. 206763 Holdings Lid., supra n. 1; Bank of Nova Scotia v. R.P. and R. Holdings Ltd. (1982) 18 Alta. L.R. (2d) 192 (Q.B., Master in Chambers) Master Quinn; Zilka v. Zilka (1978) 9 A.R. 27 (C.A.).

8. See Maple Credit Ltd. v. Xomox Investments Ltd. and Remic Development Ltd., unreported, July 2, 1982 (Alta. Q.B., M.C.), followed in Heritage Savings and Trust Co. v. Blow Out Prevention Ltd., unreported, Aug. 2, 1983 (Alta. Q.B., M.C.); Spenrath Construction Ltd. v. 206763 Holdings Ltd., supra n. 1; Martens v. First National Mortgage Co. Ltd. (1982) 24 R.P.R. 260 (B.C.S.C.); Re Heller-Natofin (Western) Ltd. and Carlton Developments Ltd. (1980) 105 D.L.R. (3d) 669 (B.C.S.C.); Chin Si-Thoo v. Berry [1978] 2 W.W.R. 641 (Man. Q.B.); Regina Steam Laundry Ltd. v. Saskatchewan Government Insurance Office [1971] 2 W.W.R. 96 (Sask. C.A.). The rate of interest on a damages claim for negligence awarded by a judge cannot normally be contracted for in advance (it would be highly unusual to contract with somebody that should he run you over with his vehicle, he will pay interest on any damage award at a specified rate of interest), and is therefore a separate issue. See, for example, Lewis v. Todd (1981) 34 N.R. 1 (S.C.C.); Hohol v. Pickering (1982) 35 A.R. 181 (Q.B.); Smith v. Horizon Aero Sports Ltd. [1982] 4 W.W.R. 431 (B.C.S.C.). 
clause, which a practitioner could make use of as a basic starting position and modify as deemed appropriate, founded on an analysis of the reported and unreported jurisprudence, would read as follows:

The borrower agrees that:

1. the covenant to pay interest does not merge in a judgment or judgments for principle, interest, or principle and interest;

2. the taking of a judgment or judgments does not operate as a merger of any covenants herein or af fect the obligation to pay interest at the rate and times aforesaid;

3. the covenant to pay interest at the rate set out in this agreement is to run on a judgment or judgments and continues so long as any principle, interest, or principle and interest, remains due on the covenant, judgment or judgments whether:

(a) due before and after default;

(b) due before and after maturity; or

(c) due before and after judgment or judgments, until said judgment or judgments have been fully paid and satisfied.

4. Section 13 of the Canada Interest Act is inapplicable to this agreement and is hereby waived. ${ }^{9}$

Two other matters remain to be noted. First, is the existence of a judicially discretionary interest provision in section 15 of the Alberta Judicature Act. ${ }^{10}$ Second, section 13 of the Canada Interest Act, by virtue of section 12 of same, applies only to Manitoba, British Columbia, Saskatchewan, Alberta, Northwest Territories and the Yukon; it is inevitably only a matter of time before section 13 is challenged on the basis of s. 15(1) of the Canadian Charter of Rights and Freedoms:11

Every individual is equal before and under the law and has the right to the equal protection and equal benefit of the law without discrimination ...

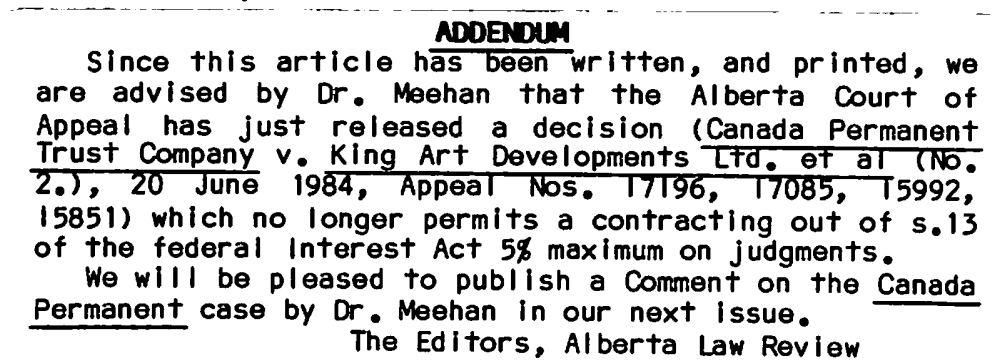

9. In a mortgage on commercial property, it should be additionally stipulated that the postjudgment interest clause applies both to recovery of the security and to the personal covenant, and any judgment thereon (and further of course that the mortgagee may realize upon the security and preserve the right to sue on the personal covenant for any deficiency, and in these days of falling real estate prices, vice versa). In British Columbia the B.C.C.A. has recently held that the federal Interest Act maximum of five percent applies to a subsequent mortgage deficiency on a personal covenant: Norfolk Trust v. Wolcoski [1982] 6 W.W.R. 190, and applies also to a stay of execution pending appeal: Wells v. Chrysler Canada Ltd. (1980) 20 B.C.L.R. 174. See also Le Blanc v. Corporation of the City of Penticton (1980) 16 C.P.C. 94 (B.C.S.C.).

10. R.S.A. 1980, c. J-1. supra n. 1. See, more recently, Eyben v. K.R. Ranches (1970) Ltd. [1982] 5 W.W.R. 269 (Alta. C.A.) and Smith and/or Irdo Holdings Ltd. v. Royal Insurance Company Limited [1983] 3 W.W.R. 577 (Alta. C.A.).

11. Constitution Act, 1982, Part 1, as enacted by the Canada Act, 1982 (U.K.) c. 11. By section 32(2) of the Constitution Act, section 15 will not be effective until April 17, 1985. 